\title{
Growth of Mediterranean young-of-the-year bluefin tuna Thunnus thynnus (Scombridae): regional differences and hatching periods
}

\author{
Ana Gordoa ${ }^{1}$, Igaratza Fraile ${ }^{2}$, Haritz Arrizabalaga ${ }^{2}$, Nuria Raventós ${ }^{1}$ \\ ${ }^{1}$ Centro de Estudios Avanzados de Blanes (CEAB-CSIC), Acc. Cala St. Francesc 14, 17300 Blanes. Spain. \\ (AG) (Corresponding author) E-mail: gordoa@ ceab.csic.es. ORCID iD: https://orcid.org/0000-0003-1822-8196 \\ (NR) E-mail: nuria@ ceab.csic.es. ORCID iD: https://orcid.org/0000-0002-1831-9947 \\ ${ }^{2}$ AZTI, Herrera Kaia portualdea z/g, 20110 Pasaia, Spain. \\ (IF) E-mail: ifraile@azti.es. ORCID iD: https://orcid.org/0000-0002-8655-2185. \\ (HA) E-mail: harri@azti.es. ORCID iD: https://orcid.org/0000-0002-3861-6316
}

\begin{abstract}
Summary: This study analyses growth rates of bluefin tuna young-of-the-year in the Mediterranean. Potential differences in growth rates were examined between years (2013 and 2016) and regions (eastern, central and western Mediterranean). A total of 134 specimens were aged by analysing otolith microstructure. Fish sizes ranged between 14.7 and $57 \mathrm{~cm}$ fork length, and estimated ages varied between 45 and 192 days. The annual growth models explained more than $90 \%$ of growth variability. The observed differences in the growth rates between $2013\left(3.2 \mathrm{~mm} \mathrm{~d}^{-1}\right)$ and $2016\left(2.7 \mathrm{~mm} \mathrm{~d}^{-1}\right)$ were not significant, whereas the daily growth rate was significantly faster in the eastern region $\left(4.01 \mathrm{~mm} \mathrm{~d}^{-1}\right)$ than in the western $(2.52$ $\left.\mathrm{mm} \mathrm{d}^{-1}\right)$ and central $\left(2.75 \mathrm{~mm} \mathrm{~d}^{-1}\right)$ regions. Larval hatching windows were consistent with the known spawning periods but lasted longer than previously reported in the central and eastern regions. In the central region the hatching period showed two peaks in mid-June and mid-July, consistent with previous studies pointing to two distinct spawning pulses. These pulses might be due to the existence of different bluefin tuna contingents spawning at different times, the Mediterranean residents and the Atlantic migrants, but further research is needed to support this hypothesis.
\end{abstract}

Keywords: daily growth; young-of-the-year; juveniles; Mediterranean; Atlantic bluefin tuna; Thunnus thynnus.

Crecimiento de los jóvenes del año de atún rojo Thunnus thynnus (Scombridae) en el Mediterráneo: diferencias regionales y períodos de eclosión

Resumen: Este estudio analiza las tasas de crecimiento de los alevines de atún rojo en el Mediterráneo. Se examinaron las posibles diferencias en las tasas de crecimiento entre diferentes años: 2013 y 2016 y diferentes regiones: oriental, central y occidental. Se determinó la edad de un total 134 ejemplares analizando la microestructura de los otolitos. Las tallas de los peces oscilaron entre 14,7 y $57 \mathrm{~cm}$ de longitud furcal, las edades estimadas variaron entre 45 y 192 días. Los modelos de crecimiento anual explicaron más del $90 \%$ de la variabilidad del crecimiento. Las diferencias observadas en las tasas de crecimiento entre $2013\left(3,2 \mathrm{~mm} \mathrm{~d}^{-1}\right)$ y $2016\left(2,7 \mathrm{~mm} \mathrm{~d}^{-1}\right)$ no fueron significativas, mientras que la tasa de crecimiento diaria fue significativamente más rápida en la región oriental $\left(4,01 \mathrm{~mm} \mathrm{~d}^{-1}\right)$ que en las regiones occidental $\left(2,52 \mathrm{~mm} \mathrm{~d}^{-1}\right)$ y central $\left(2,75 \mathrm{~mm} \mathrm{~d}^{-1}\right)$. Los periodos de eclosión de las larvas coincidieron con los periodos de desove conocidos, pero en las regiones central y oriental duraron más de lo que se había informado anteriormente. En la región central el periodo de eclosión mostró dos picos, a mediados de junio y a mediados de julio, lo que coincide con estudios anteriores que señalan dos pulsos de desove distintos. Estos pulsos podrían deberse a la existencia de diferentes contingentes de BFT, los residentes del Mediterráneo y los migrantes del Atlántico, que desovarían en momentos diferentes, pero para apoyar esta hipótesis es necesario investigar más.

Palabras clave: crecimiento diario; jóvenes del año; juveniles; Mediterráneo; atún rojo del Atlántico; Thunnus thynnus.

Citation/Como citar este artículo: Gordoa A., Fraile I., Arrizabalaga H., Raventós N. 2021. Growth of Mediterranean young-of-the-year bluefin tuna Thunnus thynnus (Scombridae): regional differences and hatching periods. Sci. Mar. 85(2): 61-69. https://doi.org/10.3989/scimar.05108.006

Editor: P. Sartor.

Received: July 30, 2020. Accepted: February 1, 2021. Published: May 28, 2021.

Copyright: (C) $2021 \mathrm{CSIC}$. This is an open-access article distributed under the terms of the Creative Commons Attribution 4.0 International (CC BY 4.0) License. 


\section{INTRODUCTION}

The Atlantic bluefin tuna (Thunnus thynnus) is a highly migratory species with a wide distribution throughout the North Atlantic Ocean and the Mediterranean Sea. The species comprises two different populations, one spawning in the Mediterranean and one in the Gulf of Mexico (Rooker et al. 2008, Rodríguez-Ezpeleta et al. 2019). These populations share common feeding grounds and exhibit a wide spatial overlap throughout the Atlantic, as revealed by satellite tags and genetic and microchemistry analyses (Boustany et al. 2008, Rooker et al. 2014, Rodríguez-Ezpeleta et al. 2019). Despite the complex population structure of Atlantic bluefin tuna (ABFT), the International Commission for the Conservation of Atlantic Tunas (ICCAT) manages it as two different stocks separated by the $45^{\circ} \mathrm{W}$ meridian. The complexity of the ABFT structure is becoming increasingly conspicuous as knowledge of it progresses. The assumption that there are only two spawning areas has been questioned (Lutcavage et al. 1999). Indirect evidence based on reproductive studies (Goldstein et al. 2007) and tag data (Block et al. 2005, Walli et al. 2009, Galuardi et al. 2010) point to the existence of undocumented spawning grounds which, at least for the Slope Sea, was definitively confirmed by Richardson et al. (2016). In addition, several authors have pointed out the possibility of additional spawning areas in the Atlantic, such as in the Canary and Azores Islands (Lutcavage et al. 1999, Di Natale and Idrissi 2012), but the lack of direct studies in these areas prevents us from drawing conclusions on the subject for the time being. However, a recent identification of ABFT larvae in the Cantabrian Sea (Rodríguez et al., 2019) is an additional piece of evidence of the high degree of complexity of the ABFT spawning structure.

The complexity of ABFT population structure is further exacerbated when the Mediterranean component is considered; this has been a subject of discussion for years, as it could have important management implications (Viñas et al. 2011, Arrizabalaga et al. 2019). The potential existence of discrete bluefin tuna subpopulations or contingents within the Mediterranean has been widely discussed (Renzoni et al. 1978, Morales-Nin and Fortuño 1990, Fromentin and Powers 2005), because the presence of bluefin tuna in the Mediterranean is not seasonal as in the Gulf of Mexico but permanent throughout the year. Genetic studies on bluefin tuna within the Mediterranean have shown different views on the existence of genetic subpopulations. Some studies have found regional differences within the Mediterranean (Viñas et al. 2003, Carlsson et al. 2004, Riccioni et al. 2010), but the most recent ones based on Single nucleotide polymorphisms and using larvae and age 0 fish as reference samples did not detect any genetic structure (Rodríguez-Ezpeleta et al. 2019). In addition, e-tagging studies have identified both resident individuals (Fromentin and Lopuszanski 2013, Cermeño et al. 2015) and fish that just use the Mediterranean to reproduce (e.g. Aranda et al. 2013, Abascal et al. 2016). A recent review suggests that more populations or contingents might exist than was previously thought, and it seems more likely that ABFT that originated in the western Mediterranean migrate to the Atlantic for feeding more intensively than those that originated in the eastern Mediterranean (Arrizabalaga et al. 2019).
Additional information also reveals differences between Mediterranean regions. The spawning grounds in the Mediterranean, determined through histological analysis and larval findings, are well known: the Balearic waters in the western Mediterranean (Medina et al. 2002), the Levantine Sea in the eastern Mediterranean (Karakulak et al. 2004), and the South Tyrrhenian Sea and the waters around Malta and off the Tunisian coast and off the eastern coast of Sicily in the central Mediterranean (e.g. Nishida et al. 1998, Corriero et al. 2003, Giovanardi and Romanelli 2010). The spawning migration path from the Atlantic to the Mediterranean has shown a strong connection with all Mediterranean spawning grounds except the Levantine Sea (Block et al. 2005, Walli et al. 2009, Arrizabalaga et al. 2019), which places the origin of the eastern spawners into question. In addition, several studies have reported differences in the fish size structure between Mediterranean spawning regions (Karakulak et al. 2004, Heinisch et al. 2008, Addis et al. 2016). The spawners in the eastern Mediterranean seem to be smaller than those entering the Mediterranean and those from the western Mediterranean spawning grounds, while sizes in the central region had a wider distribution, which might be representative of a mixing spawning ground of fish coming from the Atlantic and eastern Mediterranean (Heinisch et al. 2008).

Differences in spawning periods among Mediterranean regions are known: spawning takes place in June-July in the western basin (e.g. Susca et al. 2001, Medina et al. 2002, Corriero et al. 2003) and one month earlier, May-June, in the eastern basin (Duclerc et al. 1974, Karakulak et al. 2004, Oray and Karakulak 2005). These differences are attributed to temporal differences in water warming between regions. In the Mediterranean Sea the differences in temperature and chlorophyll between the eastern and western basins are permanent throughout the year (d'Ortenzio and Ribera d'Alcalà 2009, Skliris et al. 2012, Shaltout and Omstedt 2014). Temperature and food availability can affect growth and survival during the early stages of fish development (Anderson 1988), as evidenced in Pacific and Atlantic bluefin tuna larvae (García et al. 2013, Satoh et al. 2013, Ishihara et al. 2019). Consequently, the oceanographic differences within the Mediterranean may cause differences in the growth rate during the earlier stages of development of the species. In spite of this, no comparative studies on the larval or young-of-the-year (YOY) growth within the Mediterranean have yet been carried out. So far, studies on ABFT larval growth are limited to the larvae collected in the western spawning ground in the Balearic waters (García et al. 2006, 2013), whereas the studies on YOY are performed with juveniles caught in the central Mediterranean (Santamaria et al. 2009 La Mesa et al. 2005).

The objectives of the present study were to analyse the growth rates of ABFT YOY in the Mediterranean basin in 2013 and 2016 and investigate potential differences in growth rates between eastern, central and western regions. We analysed the microstructure of ABFT otoliths using the daily increment counts to estimate the age and growth of juveniles collected in the framework of the Grand Bluefin Tuna Year Programme (GBYP). The GBYP was officially adopted by the ICCAT Commission 
in 2008 and aims to improve basic data collection through data mining, understanding of key biological and ecological processes and assessment models, and provision of scientific advice on stock status.

\section{MATERIALS AND METHODS}

\section{Sampling}

The otoliths of ABFT YOY were taken from the GBYP biological data bank; they were sampled within the GBYP biological sampling programme in several Mediterranean regions. During the sampling, catch date was recorded and fish fork length (FL) was measured to the nearest $0.1 \mathrm{~cm}$. Each sagittal otolith was carefully extracted and cleaned. After drying, the otoliths were stored in plastic vials and kept in the GBYP data bank. The samples were requested to the GBYP for two years, 2013 and 2016, and were selected according to the specific objectives for each year. In 2013, the objective was to analyse the growth rate of YOY in the whole Mediterranean basin; a total of 60 otoliths were selected, 20 per region (eastern, western and central) and from samples caught close together in time (Fig. 1). In 2016, the objective was to analyse the growth rates for each Mediterranean region, which required a wide range of sizes in each region; consequently, for each region the otoliths were selected from two subsets of samples separated in time. The length frequency distribution of each sample, recorded in the GBYP data bank, was examined to ensure that the otoliths selected for each location represented the whole size range of the fish caught (Table 1). The juveniles collected in the Tyrrhenian Sea in August 2016 displayed a wider size range, and consequently the sample size was larger than that of those from the other regions. Another particularity of 2016 was that

Table 1. - Summary of collected data: dates, locations, number of individuals and size ranges.

\begin{tabular}{|c|c|c|c|c|c|}
\hline Year & Area & Location & Catch date & Sample size & Fork length $(\mathrm{cm})$ \\
\hline \multirow{3}{*}{2013} & Western & Balearic Islands & 19 October & 20 & $32.5-41.0$ \\
\hline & Central & Malta & 10-23 September & 20 & $19.4-27.6$ \\
\hline & Eastern & North Cyprus & 15-20 August & 20 & $21.0-26.4$ \\
\hline \multirow{8}{*}{2016} & \multirow{2}{*}{ Western } & Balearic Islands & 10-30 September & 10 & $20.4-33.1$ \\
\hline & & Balearic Islands & 2-18 November & 11 & $35.0-48.0$ \\
\hline & \multirow{3}{*}{ Central } & South Tyrrhenian & 19-29 August & 20 & $18.4-52.6$ \\
\hline & & South Tyrrhenian & 12 October & 2 & $29.5-32.6$ \\
\hline & & South Tyrrhenian & 4-17 December & 13 & $43.0-57.0$ \\
\hline & \multirow{3}{*}{ Eastern } & North Cyprus & 22-29 July & 5 & $14.7-17.1$ \\
\hline & & North Cyprus & 13-31 August & 5 & $16.1-30.4$ \\
\hline & & North Cyprus & 2-10 September & 10 & $20.5-35.8$ \\
\hline
\end{tabular}

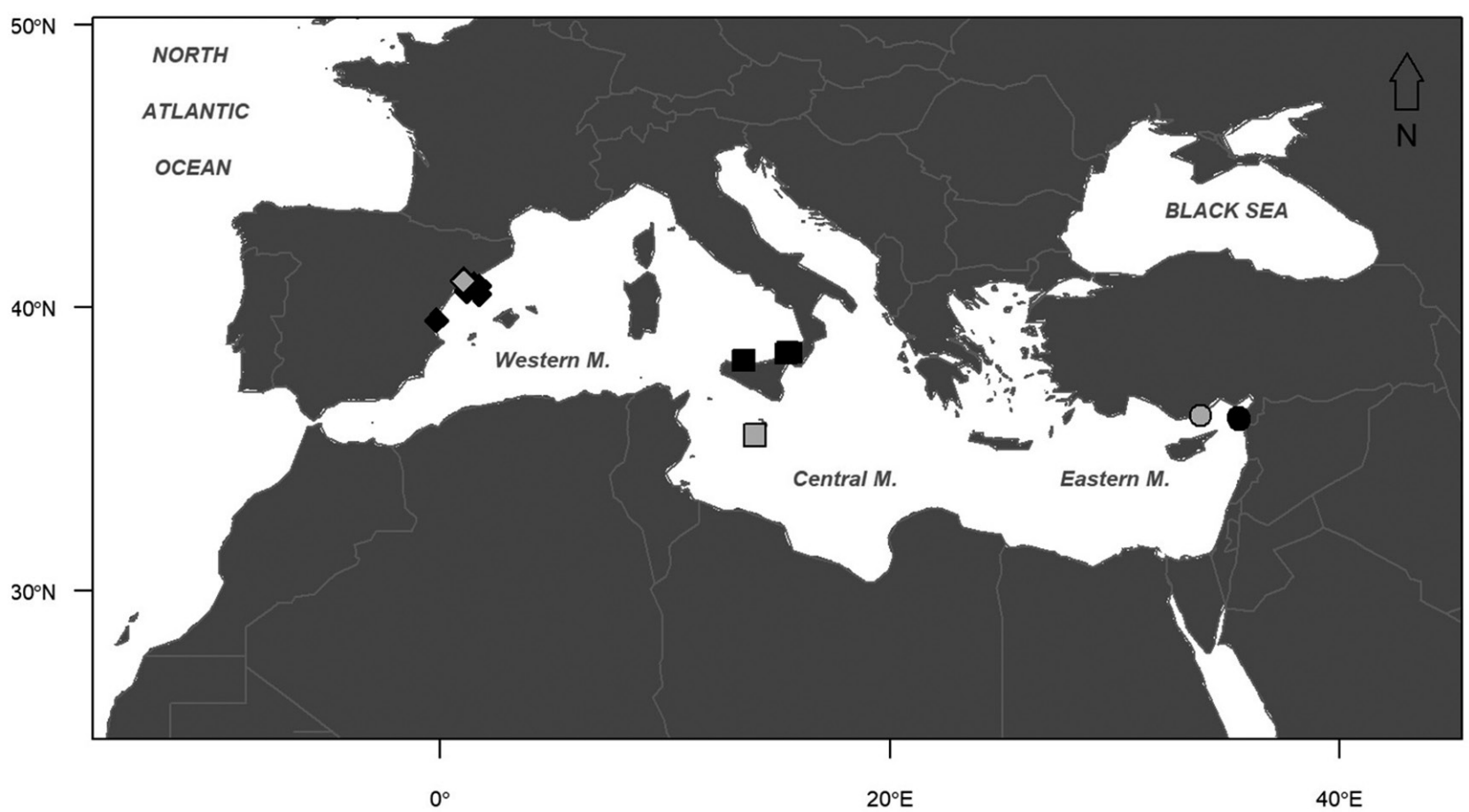

Fig. 1. - Sampling sites. Western locations (diamonds), central locations (squares) and eastern locations (circles). Symbols filled with grey and black outlines represent the years 2013 and 2016, respectively. 
only 27 juvenile individuals were collected in the eastern region, so the analysed subsample (20) represented practically all the fish available in the GBYP data bank for that year and region.

\section{Age and growth}

The ageing of 2013 and 2016 samples was carried out in two different laboratories (AZTI and CEAB) three years apart, following the same technique. When both otoliths were available, the left ones were chosen preferably for age reading; otherwise the right one was used, because no significant differences between left and right sagittal otoliths have been reported (Rooker et al. 2003, Megalofonou 2006).

In order to obtain a transverse section, the otoliths were mounted on the edge of a glass slide using a thermoplastic glue (Crystal Bond), placing the primordium just before the edge of the slide. Both the anterior and posterior ends were sequentially grinded down using wet lapping films (30 and 12 microns), resulting in a section containing the nucleus. Then, the otoliths were placed side down in the centre of the slide and the polishing procedures continued. The increment sequence was continuously checked under a compound microscope. A further, finer smoothing was done with a 1 micron lapping film until a plane including all the rings and nucleus could be observed. Grinding and polishing procedures were carried out with a Metaserv 3000 variable speed grinder-polisher. Finally, the samples were brushed with immersion oil to enhance the contrast. Each assigned age was corrected by adding four days to the total counted increments (Brothers et al. 1983, Itoh et al. 2000). Two different readings were made. In 2013, when counts differed by more than $10 \%$, a third reading was performed. If the difference in counts was greater than $10 \%$, that otolith was considered unreadable. In 2016 the third reading was considered necessary when counts differed by more than $5 \%$.

Simple linear regression models were used to determine the daily growth of YOY in the Mediterranean. Potential growth differences between years (2013 and 2016) and between regions (eastern, western and central) and basins (eastern vs western $\&$ central) were examined by comparing the slopes of the regression lines based on a Student t-test after examining the homogeneity of their variances (F-test). In order to examine the possible effect of fish size range on the estimates of growth rates, an additional analysis was carried out. The western \& central growth rate was recalculated without the larger individuals $(>380 \mathrm{~mm})$, which were absent in the samples collected from the eastern basin.

In addition, the individuals' hatching dates were back-calculated from the age estimates and date of capture to estimate the hatching windows of our samples.

\section{RESULTS}

The otolith microstructure showed a concentric pattern of increments from the core region until around the sixth increment, and then became larger and elongated along the postero-anterior axis, which was gradually reduced (Fig. 2). In 2013, 83.3\% of the readings differed

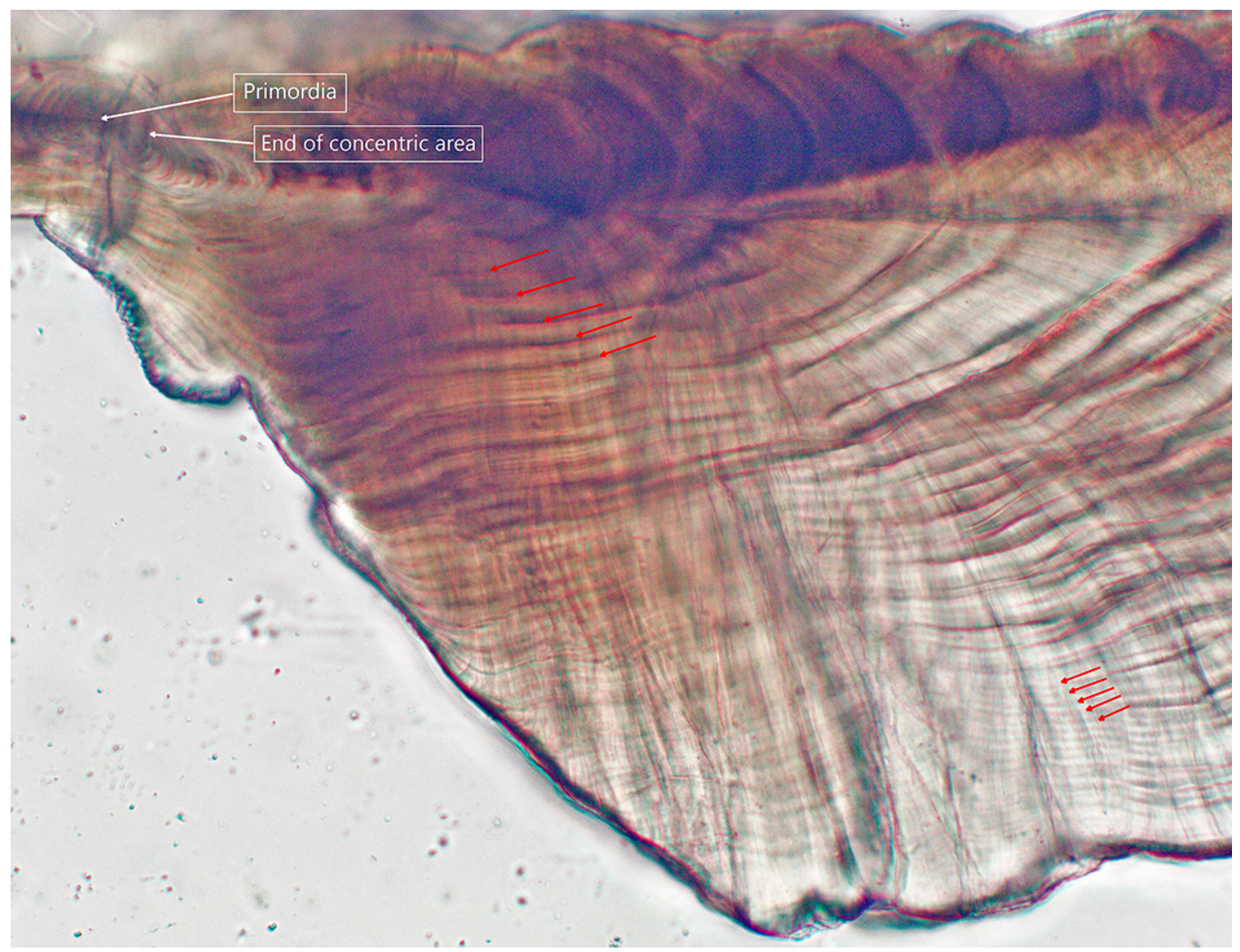

Fig. 2. - Otolith pattern of daily growth. 
from each other by less than $5 \%$, whereas $16.7 \%$ of the readings differed by $5 \%$ to $10 \%$ and no age estimate differed more than $10 \%$. In $2016,87 \%$ of the readings differed by less than $5 \%$ and the differences between the remaining percentage were below $9 \%$.

A total of 134 specimens between 14.7 and $57 \mathrm{~cm} \mathrm{FL}$ were aged. This is the largest sample size on YOY bluefin
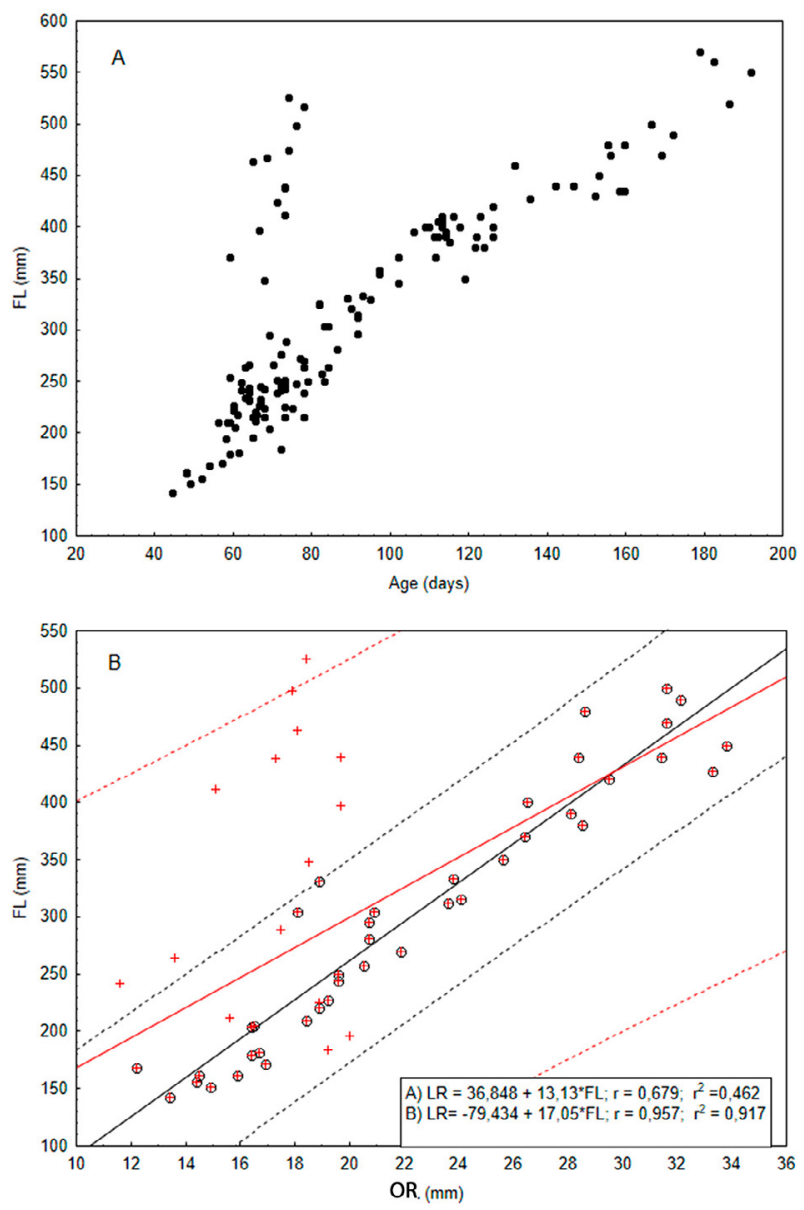

Fig. 3. - Relationship between young-of-the-year fork length and A) age in days; B) otolith radius (m). Linear regressions and confidence intervals fitted with all the observations (in red) and without the southern Tyrrhenian samples taken in August 2016 (in black).

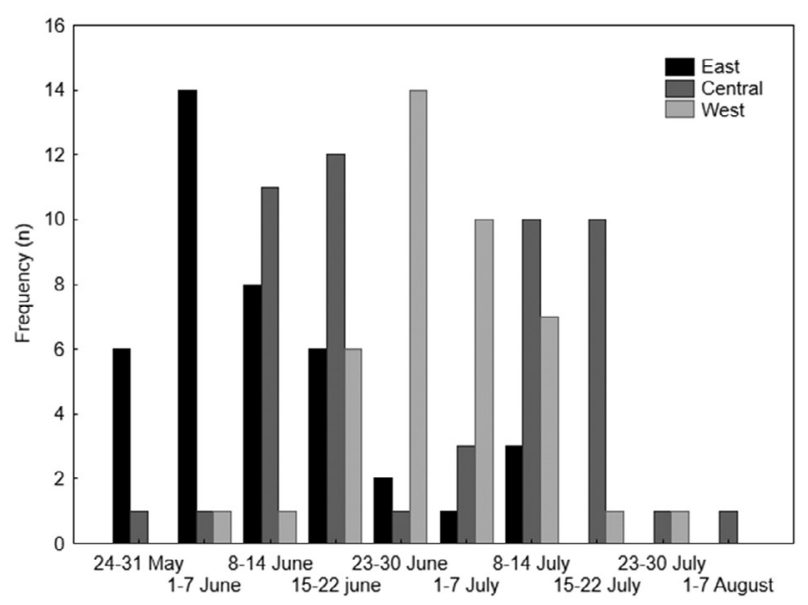

Fig. 4. - Fraction of fish born per week, area and year. tuna otolith microstructure analysis so far. Age estimates ranged from 45 to 192 days. An overview of the results (Fig. 3A) showed some abnormal observations: young individuals ( $<80$ days) with extraordinarily large sizes, even above $50 \mathrm{~cm}$. These observations corresponded to YOY caught in the Tyrrhenian Sea in August 2016. The catch was comprised of individuals with a wide length range, spanning 18.4 to $52.6 \mathrm{~cm}$ FL, but with a narrow age range (59 to 78 days). The age and length of the exceptional observations were double-checked. First, the age was re-read and the new readings confirmed the previous age estimates. Next, the reported fork lengths of the YOY captured in 2016 were examined with the size of their otoliths based on the known linear relationship between fish length (FL) and otolith length (e.g. Jenkins and Davis 1990, La Mesa et al. 2005, Gunn et al. 2008). The radius length (LR) was measured for each otolith and the linear regression between FL and LR were estimated. The model fitted with the data holding the exceptional observations only explained $46 \%$ of FL variability but increased to $92 \%$ when the sample was excluded (Fig. 3B). These results indicated that the extraordinarily large sizes in that specific sample were wrong. Consequently, every FL observation outside the $99 \%$ prediction interval was discarded from the growth analysis; a total of 13 fish were excluded from the growth analysis because their sizes
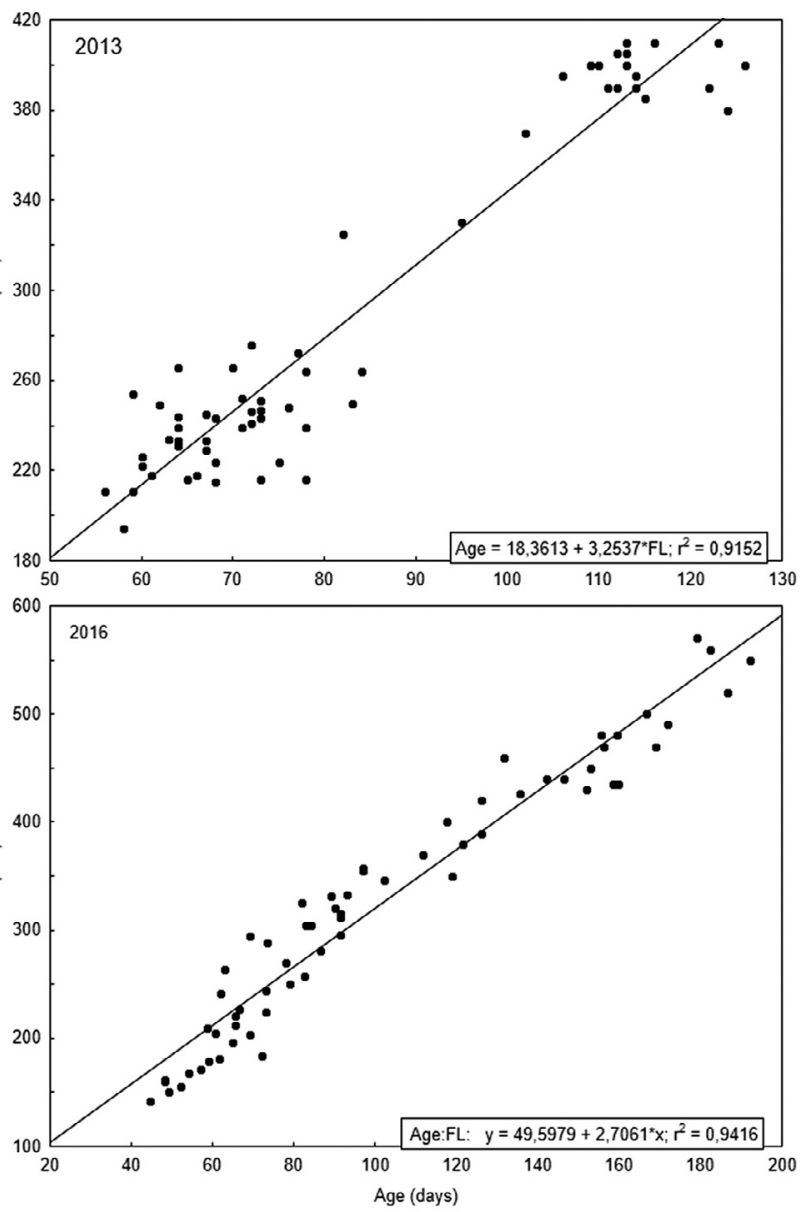

Fig. 5. - Linear regressions fitted to the age-length data of young-ofthe-year born in 2013 and 2016. 
were outside the prediction interval but their ages were included in the birth date estimations.

The birth dates found for each region varied from 24 May to 11 July in the eastern region, from 31 May to 4 August in the central region and from 2 June to 29 July in the western region. The extension of the birth intervals in the eastern and western regions was close to two months (Fig. 4). The main differences between regions (Fig. 4) were: 1) the eastern region consistently showed earlier ending and earlier hatching, with the peak around the first fortnight of June for both sampled years, 2) the hatching interval was wider in the central region than in the other regions and showed two peaks, in mid-June and in mid-July, and 3) the peak observed in the western region in late June took place between the two peaks observed in the central region.

The growth models fitted for 2013 and 2016 observations explained more than $90 \%$ of the daily growth variability of YOY in the whole Mediterranean basin (Fig. 5). The t-test analysis showed no significant differences between the growth rates of $2013\left(3.25 \mathrm{~mm} \mathrm{~d}^{-1}\right)$ and 2016 $\left(2.70 \mathrm{~mm} \mathrm{~d}^{-1}\right)$. In contrast, the results of the growth models fitted for each region separately displayed high variability, from $2.52 \mathrm{~mm} \mathrm{~d}^{-1}$ to $4.01 \mathrm{~mm} \mathrm{~d}^{-1}$ (Table 2). While the western and central regions showed no significant differences between each other, the daily growth rate of the eastern region $\left(4.01 \mathrm{~mm} \mathrm{~d}^{-1}\right)$ was significantly faster. These differences in the growth rates between basins remain after the additional analysis in the western and central basin, in which the largest fish (>380 mm) were excluded (Table 2).

\section{DISCUSSION}

Spawning onset of T. thynnus seems to be temperature-related for all tuna species (Schaefer 2001). In the Mediterranean, the reported temperatures during the ABFT spawning period range from $19.5^{\circ} \mathrm{C}$ to $26.5^{\circ} \mathrm{C}$ (García et al. 2005, Teo et al. 2007, Gordoa and Carreras 2014), but neither spawning nor water warming are simultaneous along its almost $4000 \mathrm{~km}$ of length. The time differences in spawning between regions assumed to be related to the warming time lag range from June to July in the western basin (e.g. Susca et al. 2001, Medina et al. 2002, Corriero et al. 2003) and from May to June in the eastern basin (Duclerc et al. 1974, Karakulak et al. 2004, Oray and Karakulak 2005). These spawning windows in the Mediterranean spawning regions are to a certain extent in accordance with the hatching time intervals shown in this study. However, they do not support the hypothesis of a 2016 winter spawning event based on the anomalously large YOY caught in the Tyrrhenian sea (Di Natale et al. 2017), which have been shown here to be errors.

It should be highlighted that the estimated hatching time intervals shown here may be only indicative of the minimum spawning window expected in each region. Notwithstanding this limitation, the observed hatching interval in the central Mediterranean, which spanned from the end of May to the beginning of August, was wider than the spawning window reported by previous studies. The sampling periods reported by these studies, either based on gonadal development or larval survey, were limited to May-July (Corriero et al. 2003, García et al. 2005, Heinisch et al. 2008). We must go back to 1932 to find the first and last indication of bluefin tuna spawning in August, when some larvae were found around Sicilian waters (Sanzo 1932). Currently, there is no information to infer whether spawning events in August are permanent or occasional. Similarly, in the eastern region (Levantine Sea), the hatching interval lasted until mid-July, which is well beyond the previously reported spawning period (May-June).

The results of the central region covered a wide hatching period (late May to early August) with a bimodality in the hatching frequency in mid-June and mid-July. The observed pattern could be an artefact of a weak sampling coverage. However, this is unlikely given that the expected peak under a progressive spawning process would be found in late June and/or early July, which is precisely when we observed the minimum frequency. Furthermore, these results are consistent with the length frequency bi-

Table 2. - Growth models of YOY Bluefin tuna in The Mediterranean ( $\mathrm{t}=$ days). * the model was fitted without the specimens over $380 \mathrm{~mm}$ FL.

\begin{tabular}{|c|c|c|c|c|c|c|c|}
\hline Reference & Sampling year & Area & Growth model & $\mathrm{R}^{2}$ & $\begin{array}{l}\text { Std Err } \\
\text { of } b\end{array}$ & $\mathrm{~N}$ & $\begin{array}{l}\text { FL interval } \\
(\mathrm{mm})\end{array}$ \\
\hline \multirow{8}{*}{ This study } & 2013 & Whole Mediterranean & $\mathrm{FL}=18.36+3.254 \times \mathrm{t}$ & 0.92 & 0.13 & 60 & $194-410$ \\
\hline & \multirow{4}{*}{2016} & Whole Mediterranean & $\mathrm{FL}=49.60+2.706 \times \mathrm{t}$ & 0.94 & 0.0866 & 63 & $142-570$ \\
\hline & & Eastern Mediterranean & $\mathrm{FL}=-42.75+4.012 \times \mathrm{t}$ & 0.98 & 0.1459 & 20 & $142-358$ \\
\hline & & Central (Thyrrhenian) & $\mathrm{FL}=73.34+2.521 \times \mathrm{t}$ & 0.93 & 0.1629 & 20 & $184-570$ \\
\hline & & $\begin{array}{l}\text { Western Mediterranean } \\
\text { (Balearic Islands) }\end{array}$ & $\mathrm{FL}=48.39+2.750 \times \mathrm{t}$ & 0.93 & 0.1724 & 21 & $204-480$ \\
\hline & \multirow{3}{*}{$2013 \& 2016$} & Eastern Mediterranean & $\mathrm{FL}=-24.44+3.73 \times \mathrm{t}$ & 0.92 & 0.1825 & 40 & $142-358$ \\
\hline & & $\begin{array}{l}\text { Western and Central } \\
\text { Mediterranean }\end{array}$ & $\mathrm{FL}=72.19+2.60 \times \mathrm{t}$ & 0.91 & 0.0891 & 83 & $184-570$ \\
\hline & & $\begin{array}{l}\text { Western and Central } \\
\text { Mediterranean }(*)\end{array}$ & $\mathrm{FL}=62.56+2.63 \times \mathrm{t}$ & 0.72 & 0.2441 & 46 & $184-380$ \\
\hline La Mesa et al. 2005 & 2002 & Central Mediterranean & $\mathrm{FL}=41.20+2.370 \times \mathrm{t}$ & 0.71 & NA & 56 & $195-400$ \\
\hline Santamaria et al. 2003 & $1998-2000$ & Central Mediterranean & $\mathrm{FL}=40.30+2.904 \times \mathrm{t}$ & 0.94 & NA & 24 & $112-495$ \\
\hline Megalofonou et al. 2006 & 1997-2002 & $\begin{array}{l}\text { Central Mediterranean } \\
\text { (Tyrrhenian, Ionian, Adriatic) } \\
\text { and Aegean }\end{array}$ & $\mathrm{FL}=52.00+4.700 \times \mathrm{t}$ & 0.79 & NA & 67 & $85-555$ \\
\hline
\end{tabular}


modality of YOY found by Relini et al. (1995), who suggested two different spawning pulses in the central region. The existence of different spawning pulses might be due to the existence of different bluefin tuna contingents (e.g. residents and Atlantic migrants) using the central spawning region at slightly different times, but further research is needed to support this hypothesis.

The sampled location of the YOY does not necessarily correspond to their hatching place. However, based on current knowledge, it is likely that sampling of YOYs occurred close to their hatching places in the western and eastern regions. The Mediterranean is comprised of two basins that are connected by the strait of Sicily, but each of them has a counter-clockwise surface current (Millot 1999, Hamad et al. 2005) which, in addition to the long distance between the western and eastern spawning regions, makes the exchange of YOY between western and eastern regions unlikely. The central region represents a different scenario due to its large extension, from Sicily to the Aegean Sea, which could receive some YOY from the Levantine Sea. Unfortunately, little is currently known about YOY migration capability because of the lack of scientific tagging studies for this age class.

The few studies on age and growth of YOY in the Mediterranean (Table 2) showed much faster growth rates than those reported for YOY in the western Atlantic (Brothers et al. 1983, Arai et al. 2020), which were around 1.1 to 1.5 $\mathrm{mm} \mathrm{d}^{-1}$. The results of the growth model for the central Mediterranean showed no major differences from previous estimates in this region (La Mesa et al. 2005, Santamaria et al. 2009), with the exception of the data reported by Megalofonou (2006), which differed from the rest. In the latter study, the model showed faster growth: even faster than our estimation for the eastern region. The YOY collected in that study came from a very large area, which included various seas of the central Mediterranean: the south Thyrrhenian, the Ionian, the Adriatic and also the Aegean Sea. However, it is unlikely all these fish have their origin in the central Mediterranean spawning ground. In particular, the YOY collected in the Aegean Sea may have come from the Levantine Sea because this is the closest spawning ground and the anti-clockwise direction of the surface current from the Levantine to the Aegean Sea would favour the transport of these specimens.

The present study has dealt with YOY information, and, although only individuals surviving the recruitment phase may be analysed, one might assume that they are the best adapted for each scenario. There is evidence for the Pacific bluefin tuna that offspring survival depends largely on the growth rates during the late larval phase (Tanaka et al. 2006, Watai et al. 2017). Food availability and water temperature are the critical factors affecting the growth (Heath 1992) and survival rates (Campana 1996, Meekan and Fortier 1996) of marine fish larvae. For bluefin tuna, high water temperature seems to promote larval growth rates (García et al. 2013, Satoh et al. 2013). However, the results of a recent study on Pacific bluefin tuna pointed out that both temperature and food availability have an effect on larval growth but at different stages of development (Ishihara et al. 2019).

The findings of the current study showed a significantly faster YOY growth in the eastern Mediterranean, and the results ruled out the possibility that this was due to the size range of the YOY in this region. The warmer temperature in this region compared with the western region (Shaltout and Omstedt 2014) could be an important factor determining the observed differences in growth. It is worth remembering that the results of growth rates are skewed toward higher values because only surviving individuals are analysed (Le Pape and Bonhommeau 2015), because key survival factors might change between regions.

The population structure of ABFT has been the object of debate for decades, particularly regarding the eastern Mediterranean population. The presence of fish in the Mediterranean all year around (Cermeño et al. 2015), along with the potentially smaller connectivity between the Atlantic and the eastern Mediterranean (Walli et al. 2009, Arrizabalaga et al. 2019), raises the question of the existence of a single eastern Mediterranean population or contingent. Thus, the extent to which the faster growth in the eastern Mediterranean can be attributed just to the warmer environmental conditions, excluding biological potential differences, should be further investigated.

In synthesis, we can conclude that the growth rate of ABFT YOY is faster in the eastern Mediterranean, possibly because of the warmer conditions of the region, but ontogenetic differences cannot be excluded. We suggest the possibility of occurrence of two spawning pulses in the central Mediterranean, which might correspond to the existence of two different bluefin tuna contingents (e.g. residents and Atlantic migrants) using the central spawning region at slightly different times. However, further research is needed to support this hypothesis.

\section{ACKNOWLEDGEMENTS}

This work was carried out thanks to the provision of material by the ICCAT Atlantic Wide Research Programme for Bluefin Tuna (GBYP) funded by the European Union, by several ICCAT CPCs, by the ICCAT Secretariat and by other entities (see http://www.iccat.int/ GBYP/en). In addition, the analysis was funded thanks to the contribution of a scientific contract between the CSIC and a commercial company (the Balfegó Group). The content of this paper does not necessarily reflect the point of view of ICCAT or of the other funders, which have no responsibility for them, nor does it necessarily reflect the views of the funders. In no way does it anticipate the $\mathrm{Eu}-$ ropean Commission's future policy in this area.

\section{REFERENCES}

Abascal F.J., Medina A., De la Serna J.M., et al. 2016. Tracking bluefin tuna reproductive migration into the Mediterranean Sea with electronic pop-up satellite archival tags using two tagging procedures. Fish. Oceanogr. 25: 54-66. https://doi.org/10.1111/fog.12134

Addis P., Secci M., Biancacci C., et al. 2016. Reproductive status of Atlantic bluefin tuna, Thunnus thynnus, during migration off the coast of Sardinia (western Mediterranean). Fish. Res. 181: 137-147. https://doi.org/10.1016/j.fishres.2016.04.009

Anderson J.T. 1988. A review of size dependent survival during pre-recruit stages of fishes in relation to recruitment. J. Northwest Atl. Fish. Sci. 8: 55-66. https://doi.org/10.2960/J.v8.a6 
Arai K., Graves J.E., Secor D.H.. 2020. Sub-annual cohort representation among young-of-the-year recruits of the western stock of Atlantic bluefin tuna. Fish. Res. 225: 105476. https://doi.org/10.1016/j.fishres.2019.105476

Aranda G., Medina A., Santos A., et al. 2013. Evaluation of Atlantic bluefin tuna reproductive potential in the western Mediterranean Sea. J. Sea Res. 76: 154-160. https://doi.org/10.1016/j.seares.2012.08.005

Arrizabalaga H., Arregui I., Medina A., et al. 2019. Life History and Migrations of Mediterranean Bluefin Tuna. In: Block B.A. (ed), The Future of Bluefin Tunas: Ecology, Fisheries Management, and Conservation, pp 67-93

Block B.A., Teo S.L., Walli A., et al. 2005. Electronic tagging and population structure of Atlantic bluefin tuna. Nature 434: 1121-1127. https://doi.org/10.1038/nature03463

Boustany A.M., Reeb C.A., Block B.A. 2008. Mitochondrial DNA and electronic tracking reveal population structure of Atlantic bluefin tuna (Thunnus thynnus). Mar. Biol. 156: 13-24. https://doi.org/10.1007/s00227-008-1058-0

Brothers E.B., Prince E.D., Lee D.W. 1983. Age and growth of young-of-the-year bluefin tuna, Thunnus thynnus, from otolith microstructure. NOAA Tech. Report NMFS 8: 49-59.

Campana S.E. 1996. Year-class strength and growth rate in young Atlantic cod Gadus morhua. Mar. Ecol. Prog. Ser. 135: 21-26. https://doi.org/10.3354/meps135021

Carlsson J., McDowell J., Díaz-Jaimes P., et al. 2004. Microsatellite and mitochondrial DNA analyses of Atlantic bluefin tuna (Thunnus thynnus thynnus) population structure in the Mediterranean Sea. Mol. Ecol. 13: 3345-3356. https://doi.org/10.1111/j.1365-294X.2004.02336.X

Cermeño P., Quîlez-Badia G., Ospina-Alvarez A., et al. 2015. Electronic tagging of Atlantic bluefin tuna (Thunnus thynnus, L.) reveals habitat use and behaviors in the Mediterranean Sea. PLoS ONE 10: e0116638. https://doi.org/10.1371/journal.pone.0116638

Corriero A., Desantis S., Deflorio M., et al. 2003. Histological investigation on the ovarian cycle of the bluefin tuna in the western and central Mediterranean. J. Fish. Biol. 63: 108-119. https://doi.org/10.1046/j.1095-8649.2003.00132.x

d'Ortenzio F., Ribera d'Alcalà M. 2009. On the trophic regimes of the Mediterranean Sea: a satellite analysis. Biogeosciences 6: $139-148$. https://doi.org/10.5194/bg-6-139-2009

Di Natale A., Idrissi M. 2012. 2011 ICCAT Atlantic Wide Research Programme for bluefin tuna (GBYP). Coordination Detailed Activity Report For Phase 2. Collect. Vol. Sci. Pap. ICCAT 68: 176-207.

Di Natale A., Tensek S., Celona A., et al. 2017. Another peculiar situation for YOY of bluefin tuna (Thunnus thynnus) in the Mediterranean Sea in 2016. ICCAT Collect. Vol. Sci. Pap. 74: 2839-2849.

Duclerc J., Piccinetti C., Piccinetti Manfrin G., et al. 1974. Nouvelles donne sur la reproduction du thon rouge et d'autres espèces de thonidés en Méditerranée. Rapp. Comm. Int. Mer Médit 22: 37

Fromentin J.M., Powers J.E. 2005. Atlantic bluefin tuna: population dynamics, ecology, fisheries and management. Fish Fish 6: 281-306. https://doi.org/10.1111/j.1467-2979.2005.00197.x

Fromentin J.-M., Lopuszanski D. 2013. Migration, residency, and homing of bluefin tuna in the western Mediterranean Sea. ICES J. Mar. Sci. 71: 510-518 https://doi.org/10.1093/icesjms/fst157

Galuardi B., Royer F., Golet W., et al. 2010. Complex migration routes of Atlantic bluefin tuna (Thunnus thynnus) question current population structure paradigm. Can. J. Fish. Aquat. Sci. 67: 966-976. https://doi.org/10.1139/F10-033

García A., Alemany F., De la Serna J., et al. 2005. Preliminary results of the 2004 bluefin tuna larval surveys off different Mediterranean sites (Balearic Archipelago, Levantine Sea and the Sicilian Channel). ICCAT Col. Vol. Sci. Pap. 58: 1261-1270.

García A., Cortés D. Ramírez T., et al. 2006. First data on growth and nucleic acid and protein content of field-captured Mediterranean bluefin (Thunnus thynnus) and albacore (Thunnus alalunga) tuna larvae: a comparative study. Sci. Mar. 70: 67-78.

https://doi.org/10.3989/scimar.2006.70s267
García A., Cortés D., Quintanilla J., et al. 2013. Climate-induced environmental conditions influencing interannual variability of Mediterranean bluefin (Thunnus thynnus) larval growth. Fish. Oceanogr. 22: 273-287. https://doi.org/10.1111/fog.12021

Giovanardi O., Romanelli M. 2010. Preliminary note on tuna larvae in samples from the coasts of the southern-central Mediterranean Sea collected by the MV Arctic Sunrise in June/July 2008. ICCAT Col Vol Sci Pap 65: 740-743.

Goldstein J., Heppell S., Cooper A., et al. 2007. Reproductive status and body condition of Atlantic bluefin tuna in the Gulf of Maine, 2000-2002. Mar. Biol. 151: 2063-2075. https://doi.org/10.1007/s00227-007-0638-8

Gordoa A., Carreras G. 2014. Determination of Temporal Spawning Patterns and Hatching Time in Response to Temperature of Atlantic Bluefin Tuna (Thunnus thynnus) in the Western Mediterranean. PLoS ONE 9: e90691. https://doi.org/10.1371/journal pone.0090691

Gunn J.S., Clear N.P., Carter T.I., et al. 2008. Age and growth in southern bluefin tuna, Thunnus maccoyii (Castelnau): direct estimation from otoliths, scales and vertebrae. Fish. Res. 92: 207-220. https://doi.org/10.1016/j.fishres.2008.01.018

Hamad N., Millot C., Taupier-Letage I. 2005. A new hypothesis about the surface circulation in the eastern basin of the Mediterranean Sea. Prog. Oceanogr. 66: 287-298. https://doi.org/10.1016/j.pocean.2005.04.002

Heath M. 1992. Field investigations of the early life stages of marine fish. Pages 1-174 Advances in Mar. Biol. Elsevier. https://doi.org/10.1016/S0065-2881(08)60039-5

Heinisch G., Corriero A., Medina A. et al, 2008. Spatial-temporal pattern of bluefin tuna (Thunnus thynnus L. 1758) gonad maturation across the Mediterranean Sea. Mar. Biol. 154: $623-630$ https://doi.org/10.1007/s00227-008-0955-6

Ishihara T., Watai M., Ohshimo S., et al. 2019. Differences in larval growth of Pacific bluefin tuna (Thunnus orientalis) between two spawning areas, and an evaluation of the growth-dependent mortality hypothesis. Environ Biol Fishes 102: 581-594. https://doi.org/10.1007/s10641-019-00855-w

Itoh T., Shiina Y., Tsuji S., et al. 2000. Otolith daily increment formation in laboratory reared larval and juvenile bluefin tuna Thunnus thynnus. Fish Sci 66: 834-839. https://doi.org/10.1046/i.1444-2906.2000.00135.x

Jenkins G.P., Davis T.L. 1990. Age, growth rate, and growth trajectory determined from otolith microstructure of southern bluefin tuna Thunnus maccoyii larvae. Mar. Ecol. Prog. Ser. 63: 93-104. https://doi.org/10.3354/meps063093

Karakulak S., Oray I., Corriero A., et al. 2004. Evidence of a spawning area for the bluefin tuna (Thunnus thynnus L.) in the eastern Mediterranean. J. Appl. Ichthyol. 20: 318-320. https://doi.org/10.1111/j.1439-0426.2004.00561.x

La Mesa M., La Mesa G., Micalizzi M. 2005. Age and growth of madeira scorpionfish, Scorpaena maderensis Valenciennes, 1833, in the central Mediterranean. Fish. Res. 74: 265-272. https://doi.org/10.1016/i.fishres. 2005.01.018

Le Pape O., Bonhommeau S. 2015. The food limitation hypothesis for juvenile marine fish. Fish Fish 16: 373-398. https://doi.org/10.1111/faf.12063

Lutcavage M.E., Brill R.W., Skomal G.B., et al. 1999. Results of pop-up satellite tagging of spawning size class fish in the Gulf of Maine: do North Atlantic bluefin tuna spawn in the mid-Atlantic? Can. J. Fish. Aquat. Sci. 56: 173-177. https://doi.org/10.1139/f99-016

Medina A., Abascal F., Megina C., et al. 2002. Stereological assessment of the reproductive status of female Atlantic northern bluefin tuna during migration to Mediterranean spawning grounds through the Strait of Gibraltar. J. Fish. Biol. 60: 203-217. https://doi.org/10.1111/j.1095-8649.2002.tb02398.x

Meekan M.G., Fortier L. 1996. Selection for fast growth during the larval life of Atlantic cod Gadus morhua on the Scotian Shelf. Mar. Ecol. Prog. Ser. 137: 25-37. https://doi.org/10.3354/meps137025

Megalofonou P. 2006. Comparison of otolith growth and morphology with somatic growth and age in young-of-the-year bluefin tuna. J. Fish. Biol. 68: 1867-1878. https://doi.org/10.1111/j.1095-8649.2006.01078.x 
Millot C. 1999. Circulation in the western Mediterranean Sea. J. Mar. Syst. 20: 423-442. https://doi.org/10.1016/S0924-7963(98)00078-5

Morales-Nin B., Fortuño J.M. 1990. Mercury body burden and otolith characteristics of bluefin tuna from the northwest Mediterranean (Balearic Sea). Sci. Mar. 54: 277-285.

Nishida T., Tsuji S., Segawa K. 1998. Spatial data analyses of Atlantic bluefin tuna larval surveys in the 1994 ICCAT BYP. ICCAT Col. Vol. Sci. Pap. 48: 107-110.

Oray I., Karakulak F. 2005. Further evidence of spawning of bluefin tuna (Thunnus thynnus L., 1758) and the tuna species (Auxis rochei Ris., 1810, Euthynnus alletteratus Raf., 1810 ) in the eastern Mediterranean Sea: preliminary results of TUNALEV larval survey in 2004. J. Appl. Ichthyol. 21: 236-240. https://doi.org/10.1111/j.1439-0426.2005.00658.x

Relini M., G. Palandri, Torchia G. 1995. Tagging of Thunnus thynnus juveniles in the Ligurian Sea, Autumn 1994. ICCAT Col Vol Sci Pap ICCAT 44: 378.

Renzoni A., Bernhard M., Sara R., et al. 1978. Comparison between the $\mathrm{Hg}$ body burden of Thunnus thynnus from the Mediterranean and the Atlantic. IV Journées Etud. Pollutions.

Riccioni G., Landi M., Ferrara G., et al. 2010. Spatio-temporal population structuring and genetic diversity retention in depleted Atlantic bluefin tuna of the Mediterranean Sea. Proc. Nat. Acad. Sci. 107: 2102-2107. https://doi.org/10.1073/pnas.0908281107

Richardson D.E., Marancik K.E., Guyon J.R., et al. 2016. Discovery of a spawning ground reveals diverse migration strategies in Atlantic bluefin tuna (Thunnus thynnus). Proc. Nat. Acad. Sci. 113: 3299-3304. https://doi.org/10.1073/pnas.1525636113

Rodriguez J.M., Johnstone C. Lozano-Peral D. 2019. Is the Southern Bay of Biscay a spawning ground for Thunnus thynnus and Sarda sarda? ICCAT SCRS/2019/201.

Rodríguez-Ezpeleta N., Díaz-Arce N., Walter J.F., et al. 2019. Determining natal origin for improved management of Atlantic bluefin tuna. Front. Ecol. Environ. 17: 439-444 https://doi.org/10.1002/fee.2090

Rooker J.R., Secor D.H., Zdanowicz V.S., et al. 2003. Identification of Atlantic bluefin tuna (Thunnus thynnus) stocks from putative nurseries using otolith chemistry. Fish. Oceanogr. 12: $75-84$. https://doi.org/10.1046/j.1365-2419.2003.00223.x

Rooker J.R., Secor D.H., De Metrio G., et al. 2008. Natal homing and connectivity in Atlantic bluefin tuna populations. Science 322: 742-744. https://doi.org/10.1126/science.1161473

Rooker J.R., Arrizabalaga H., Fraile I., et al. 2014. Crossing the line: migratory and homing behaviors of Atlantic bluefin tuna. Mar. Ecol. Prog. Ser. 504: 265-276. https://doi.org/10.3354/meps10781

Santamaria N., Bello G., Corriero A., et al. 2009. Age and growth of Atlantic bluefin tuna, Thunnus thynnus (Osteich- thyes: Thunnidae), in the Mediterranean Sea. J. Appl. Ichthyol. 25 : $38-45$

https://doi.org/10.1111/j.1439-0426.2009.01191.x

Sanzo L. 1932. Uova e primi stadi larvali di tonno (Orcynus thynnus Ltkn.). Mem. R. Com. Talass. Ital. 189: 1-16. https://doi.org/10.1080/11250003209429197

Satoh K., Tanaka Y., Masujima M., et al. 2013. Relationship between the growth and survival of larval Pacific bluefin tuna, Thunnus orientalis. Mar. Biol. 160: 691-702. https://doi.org/10.1007/s00227-012-2124-1

Schaefer K.M. 2001. Reproductive biology of tunas. Fish Physiol.19: 225-270. https://doi.org/10.1016/S1546-5098(01)19007-2

Shaltout M., Omstedt A. 2014. Recent sea surface temperature trends and future scenarios for the Mediterranean Sea. Oceanologia 56: 411-443. https://doi.org/10.5697/oc.56-3.411

Skliris N., Sofianos S., Gkanasos A., et al. 2012. Decadal scale variability of sea surface temperature in the Mediterranean Sea in relation to atmospheric variability. Ocean Dyn. 62: 13-30. https://doi.org/10.1007/s10236-011-0493-5

Susca V., Corriero A., Deflorio M., et al. 2001. New results on the reproductive biology of the bluefin tuna (Thunnus thynnus) in the Mediterranean. ICCAT Col Vol Sci Pap 52: 745-751.

Tanaka Y., Satoh K., Iwahashi M., et al. 2006. Growth-dependent recruitment of Pacific bluefin tuna Thunnus orientalis in the northwestern Pacific Ocean. Mar. Ecol. Prog. Ser. 319: 225-235. https://doi.org/10.3354/meps319225

Teo S.L., Boustany A.M., Block B.A. 2007. Oceanographic preferences of Atlantic bluefin tuna, Thunnus thynnus, on their Gulf of Mexico breeding grounds. Mar. Biol. 152: 1105-1119. https://doi.org/10.1007/s00227-007-0758-1

Viñas J., Pla C., Tawil M., et al. 2003. Mitochondrial genetic characterization of bluefin tuna (Thunnus thynnus) from three Mediterranean (Libya, Malta, Tunisia); and one Atlantic locations (Gulf of Cadiz). ICCAT Col Vol Sci Pap 55: 1282-1288.

Viñas J., Gordoa A., Fernández-Cebrián R., et al. 2011. Facts and uncertainties about the genetic population structure of Atlantic bluefin tuna (Thunnus thynnus) in the Mediterranean. Implications for fishery management. Rev. Fish Biol. Fish. 21: 527-541. https://doi.org/10.1007/s11160-010-9174-6

Walli A., Teo S.L., Boustany A., et al. 2009. Seasonal movements, aggregations and diving behavior of Atlantic bluefin tuna (Thunnus thynnus) revealed with archival tags. PLoS ONE 4: e6151. https://doi.org/10.1371/journal.pone.0006151

Watai M., Ishihara T., Abe O., et al. 2017. Evaluation of growth-dependent survival during early stages of Pacific bluefin tuna using otolith microstructure analysis. Mar. Freshw. Res. 68: 2008-2017. https://doi.org/10.1071/MF16337 